\title{
ILUSTRADORES, AUTORES E TRADUTORES
}

\author{
Luigi Pirandello
}

Tradução de Diego Silveira Coelho Ferreira ${ }^{1}$ Andréia Guerini 1 ${ }^{1}$ Universidade Federal de Santa Catarina, Florianópolis, SC, Brasil

Resumo: Tradução do texto em italiano "Illustratori, attori e traduttori", de Luigi Pirandello, para o português brasileiro. Palavras-chave: Tradutor; Pirandello; Tradução

\section{ILLUSTRATORS, AUTHORS AND TRANSLATORS}

\begin{abstract}
Translation of the Italian text "Illustratori, attori e traduttori", by Luigi Pirandello, into Brazilian Portuguese.
\end{abstract}

Keywords: Translator; Pirandello; Translation

Há algum tempo voltou a ficar de moda, inclusive em prestígio e honra, a ilustração do livro. Vimos ilustrados inclusive livros de poesia lírica, o que já diz tudo. E a nova barbárie científica chegou a ilustrar, na França, por meio da fotografia, romances e contos.

De fato, nestas últimas obras, exemplares de um assim denominado realismo que, não conseguindo ver na arte a própria natureza que se serve do instrumento da fantasia humana para criar uma obra superior, e retornando às antiquíssimas dissertações sobre o fim e o objeto da arte já varridas do mapa pela saudável crítica estética, 
pretende restringir a arte à imitação pura e simples da natureza; para essas obras, portanto, que não têm outra ambição se não a de parecer uma fotografia da vida contemporânea, dever-se-ia pedir para aparar aquela nova espécie de ilustração, com a maquininha.

Lembro no Notre Cceur, de Maupassant, do romancista Lamarthe: "arme d'un oeil qui cueillait les images, les attitudes et les gestes avec la précision d'un appareil photographique”.

Sob o personagem de Lamarthe se escondia o próprio Maupassant, a quem - como sabemos - Flaubert havia dado esta receita máxima: "Preste atenção!", na qual, a seu ver, consistia toda a arte.

"Dê uma volta, e você me contará em cem linhas tudo o que viu".

Mas tanto Flaubert quanto Maupassant, eminentes artistas, não se tornaram - a despeito da teoria - dois fotógrafos. Não só isso, o primeiro não conseguiu nem mesmo se tornar um naturalista de verdade.

A diferença entre natureza e arte, constituída justamente pela mudança que a arte imprime à natureza, é evidentíssima de fato no desdém irônico de Flaubert (que concluiu como humorista com Bouvard et Péchuchet, irmãos ou filhos de Dupuis et Colone!), desdém irônico pela rasa realidade descrita como sistema e odiada por instinto; e é também evidentíssima na proposta de Maupassant de opor constantemente o instinto seguro e firme à razão incerta e vacilante, mostrando a própria bestialidade como o fundo de nosso ser, fundo sólido que só pode nos manter contra os caprichos da imaginação e os erros do intelecto. ${ }^{1}$

Pintores, portanto, não fotógrafos; e pintores não à maneira que pretendia Blaise Pascal, que, referindo-se claramente a um conceito já expresso por Aristóteles na Poética - e repetido por tantos outros -, desconsiderando a refração dos objetos no espírito do artista e

1 Ver Georges Pellissier, Le mouvement littéraire contemporaine, Hachette et Cie, Paris, 1901. Mas, na verdade, Pellissier não admite qualquer modificação, qualquer alteração no Maupassant das imagens reais, como se Maupassant não tivesse um modo particular de ver, de pensar, de sentir; como se já na própria escolha das representações esse particular modo de ver, de pensar, de sentir, não se afirmasse explicitamente!

Cad. Trad., Florianópolis, v. 40, nº 2, p. 465-485, mai-ago, 2020. 
crendo que a pintura não tivesse outro propósito senão o de despertar a admiração "pour le ressemblance des choses dont nous n'admirons pas les originaux", exclamava: "Que vaidade a pintura!”.

Retornemos à ilustração.

Será que a ausência de obras por si mesmas ilustradas é responsável pelo triunfo, hoje, dos ilustradores? Trocadilho, facílima polêmica, mas que vem espontaneamente à cabeça, haja vista como os ilustradores triunfam nos dias de hoje não somente nos livros, nas resenhas, nos jornais, mas em todos os lados - inclusive, digase de passagem, na música.

O músico que pega um drama, ou uma pequena obra dramática, mas completo em si mesmo (digamos, Tosca ou a Fedora), e que o enquadra e o orna com comentários orquestrais, aplicando-lhe aqui e acolá algum desenho melódico, não está agindo, ainda que em outro campo, também ele como um ilustrador?

Sabe-se que, a rigor, o libreto de uma ópera deveria ser quase ininteligível à leitura, deveria parecer mutilado, incompleto enquanto obra de arte. Quer dizer, deveria deixar o leitor em suspenso, insatisfeito, com o desejo vivo, irrequieto, em função de algo que não é acessório, mas substancial: a música que, unida e fundida com o libreto, deveria formar a obra de arte inteira: a ópera.

Quem musica Tosca ou Fedora mostra não entender, ou não querer entender, o que é ou deve ser uma ópera, pela simplicíssima razão de que a música em tais dramas, seja lá como se realize, representa não apenas um contorno supérfluo e ocioso, mas - no sentido clássico da palavra - uma contaminação indigna.

O mesmo ocorre inversamente, em meu modo de ver, e não falo nem do desenho fotográfico, mas do desenho artístico num livro de poesia.

Porque se aquela - a música - ofende porque coloca o sentimento vago, que é próprio de suas formas e de seus modos, entre as ideias e as representações precisas de um drama realista, o desenho ofende porque determina demasiadamente e quase enrijece numa expressão demasiadamente precisa as imagens do poeta, quando não as falsifica. 
É o problema estético já há tanto tempo colocado e resolvido por Lessing contra as ideias de Spencer sobre a estreita união de poesia e pintura entre os antigos, e do conde de Caylus, que julgava de maior ou menor valor uma poesia segundo pudesse ou não ser traduzida por um pintor em quadros: problema estético que Croce, equivocadamente, ao crer que a relação entre o fato estético, ou seja, a visão artística, e o fato físico, ou seja, o instrumento que serve de auxílio à reprodução, seja puramente extrínseca, declara inexistente; e que para Cesareo, no entanto, a prática, a técnica, o trabalho devem ser espontâneos e quase inconscientes. A ciência adquirida não pode ser aplicada por meio da reflexão; a técnica deve ter se tornado no artista quase um instinto. E é justamente criar em si esse instinto nobre e seguro, essa espécie de fatalidade que, sob a ação do desejo, faça responder à imagem o movimento que a expressa, apropriar-se da linguagem técnica da arte até falá -la naturalmente, é a primeira condição do verdadeiro artista.

É nesse sentido que devem ser entendidos na arte a atividade prática, a técnica, os meios comunicativos da representação, o fato físico em relação ao fato estético, cuja unidade não se salva, mas se compromete, vendo dois fatos onde na verdade há um fato apenas. E então se entenderá facilmente que esse fato estético não pode ser um, igual para todas as artes; que a diversidade exterior nas várias artes implica que seja diferente também o fato interior. Um artista não é feito pelo acaso ou pela atividade prática, como entende Croce, seja ele pintor, músico ou poeta. Quem de uma paisagem captura uma impressão em vez de uma imagem: quem, mais que visões precisas, vislumbra formas vagas, mas ainda assim tem a alma comovida por profundos sentimentos, encontra na música a sua linguagem natural. $\mathrm{O}$ pensamento do pintor é uma visão; a lógica do pintor é, por assim dizer, o jogo expressivo de uma luz que ora brilha ou se atenua, e os seus sentimentos têm uma cor, uma forma, ou melhor, a cor e a forma são para ele sentimentos.

E realmente o poeta é menos limitado que o pintor e menos livre que o músico. Sem dúvidas às vezes ocorre - e disso temos tantos exemplos - que um escritor de imaginação pictórica veja mais do 
que pense, e que um pintor filósofo pense em vez de ver. O escritor dissolve em dez páginas aquilo que deveria ter sido colhido com um olhar; o pintor sobrepõe as próprias ideias sucessivas numa imagem que se divide como o ato pelo espírito que a concebeu. Nos dois casos, o quadro necessitará um comentário: aquele do pintor para ser compreendido, aquele do escritor para ser visto.

"Quando Lessing, no Laocoonte", escreve Cesareo, "marcou os limites entre pintura e poesia, ele não se referiu se não a uma questão de técnica; nem se pode dizer que tenha errado. A técnica da pintura, que é representação de um momento no espaço, exclui por isso qualquer sucessão de tempo: pela lei física, não podemos ver ao mesmo tempo dois aspectos distintos da mesma coisa. Assim, a técnica da poesia, que é representação de mais momentos consecutivos no tempo, exclui, por outro lado, o atraso excessivo sobre os detalhes de cada momento: pela lei psicológica, não podemos capturar a imagem única e inteira de coisas evocadas em momentos distintos. Quanto mais repentina é a percepção sensível da coisa, tanto mais será proibido ao poeta esmiuçá-la em suas partes; a obra de arte não é percepção, mas é regulada por resultados experimentais desta: agora, uma percepção única e sintética não pode se romper em mais sensações tardias, analíticas, impróprias. Isso seria uma decomposição da concreta unidade da percepção num sistema de sensações: o indivíduo seria expresso não psicologicamente, mas logicamente. É lícito que o poeta represente sucessivas percepções no tempo; não é lícito que ele descreva as particularidades de uma visão instantânea no espaço. Por isso, os retratos com feições de homem ou de mulher, as prolixas descrições de natureza viva ou de natureza morta, que agradavam a Zola, a decantação em versos do conteúdo de pinturas célebres e outros tantos exercícios de preguiçosos não são definitivamente poesia. Mas, dir-se-á, então, como deve um poeta representar sua intuição de beleza, uma mulher, um jardim, um mar tempestuoso, o céu estrelado, e assim por diante? Como, não dá para dizer: existem normas para a crítica da expressão, não para sua produção: é preciso apenas que o poeta não seja contrário a técnica de sua 
arte". E Cesareo recorda o modo como Dante representa a beleza de Beatriz, e Leopardi, a de Sílvia e de Nerina; e cita o velho, mas sempre significativo, exemplo de Homero, que não descreve a beleza de Elena senão com o espanto dos velhos homens de Tróia ao passar da mulher fatal; e, por fim, o exemplo de Ariosto, sobre o qual Lessing também se deteve, na descrição de Alcina.

Por tudo isso fica claro que a pintura é mais limitada que a poesia; e que por isso um ilustrador, por mais que interprete bem o sentimento do poeta, não conseguirá nunca, pela própria natureza de sua arte, ressaltar aquilo que há de flutuante na expressão poética. O sentimento tornado visível, condensado nos contornos do desenho, por assim dizer, torna-se antes de mais nada sensação. As imagens do poeta, fixas, atacam.

Isso, repito, quando o ilustrador não falsifica, isto é, não interpreta mal a imagem expressa pelo poeta. E a interpretação fiel é tão difícil, para não dizer impossível! Quanto mais capaz é o artista, mais ele vê e se expressa de um modo todo particular. Três pintores colocados nas mesmas condições de luz e ambiente, a retratar alguém ali diante deles, vivo e arfante, farão três retratos diferentes. Imaginemos, pois, o que eles fariam com uma figura ideal, uma cena falsa num livro! Que o diga qualquer um que tenha tido a sorte de ter um romance ou um conto seu publicado numa revista ilustrada.

De outro ponto de vista, da impossibilidade ou quase de uma fiel interpretação pode falar quem escreveu ou escreve para o teatro. Porque, na arte dramática, o que é a cena se não um grande desenho vivo, em ação? O que são os comediantes se não ilustradores, também?

Mas, infelizmente, ilustradores necessários, aqui.

Quando nós lemos um romance ou um conto, nos esforçamos em imaginar os personagens e as cenas à medida que nos são descritos e representados pelo autor. Agora, suponhamos por um instante que esses personagens, de repente, por um milagre, saltem do livro vivos diante de nós, no nosso quarto, e comecem a falar com suas vozes e a se mexer e a realizar sua ação sem a sustentação descritiva ou narrativa do livro. 
Nada de mais! Esse milagre é justamente realizado pela arte dramática.

Vocês se lembram do belo romance fantástico de Heinrich Heine sobre Jaufré Rudel e Melisenda?

No castelo de Blaya, todas as noites se ouve um tremor, um rangido, um sussurro: as figuras das tapeçarias, de repente, começam a se mover. $\mathrm{O}$ trovador e a dama brandem os membros adormecidos de fantasmas, descem da parede e caminham para cima e para baixo pelo salão.

Aqui, o milagre é operado pelo raio de lua no velho castelo desabitado. As grandes tragédias gregas operaram nele, dando origem a uma poderosa alma lírica nas grandiosas figuras da magnífica tapeçaria da epopeia e das antigas lendas helênicas. Shakespeare também o operou, destacando, das histórias romana e inglesa, as figuras mais trágicas e complexas, e outras das engenhosas tramas dos contos italianos.

Mas para que das páginas escritas os personagens saltem vivos e se movam por si mesmos é preciso que o dramaturgo encontre a palavra que seja a própria ação falada, a palavra viva que mova, a expressão imediata, intrínseca ao ato, a expressão única, que não pode ser se não aquela, isto é, própria àquele dado personagem naquela dada situação; palavras, expressões que não se inventam, mas que nascem quando o autor realmente se identificou com sua criatura a ponto de senti-la como ela se sente, de querê-la como ela se quer.

O fenômeno mais elementar que se encontra ao fundo de toda obra de arte é este: uma imagem (isto é, aquela espécie de ser imaterial, porém vivo, que o artista concebeu e desenvolveu com a atividade criadora do espírito), uma imagem que tende a se tornar - como já dissemos - o movimento que a efetua, a torna real, exterior, fora do artista. A execução precisa saltar viva da concepção e apenas por seu mérito, por um movimento não provocado industriosamente, mas livre, isto é, promovido pela própria imagem, que quer se libertar, traduzir-se em realidade e viver. Trata-se de criar, já dissemos, uma realidade que, como a imagem, seja ao mesmo tempo material e espiritual, uma aparência que seja a ima- 
gem, mas tornada sensível. Ao complexo de imagens organizadas na concepção artística deverá corresponder um complexo de movimentos organizados, combinados segundo as mesmas relações e que tendem a criar uma aparência que, sem alterar as características próprias da imagem, sem romper minimamente sua harmonia de fato espiritual, a faça entrar no mundo real. Dever-se-iam se encontrar na execução, pois, todas as características da concepção. Pode isso ocorrer na arte dramática?

Infelizmente, sempre, entre o autor dramático e a sua criatura, na materialidade da representação, introduz-se necessariamente um terceiro elemento imprescindível: o ator.

Esta, como se sabe, é para a arte dramática uma submissão inevitável.

Tal como o autor que, para fazer uma obra viva, precisa se identificar com sua criatura até senti-la como ela se sente, até querê-la como ela se quer, deveria fazer o ator, se isso fosse possível.

Mas também quando se encontra um grande ator, que consegue se despir de toda sua própria individualidade para entrar naquela do personagem que ele deve representar, a encarnação plena e perfeita é em geral obstaculizada por razões de fato irremediáveis: pela própria figura do ator, por exemplo. Esse inconveniente é reparado, pelo menos em parte, com a maquiagem. Mas temos sempre uma adaptação, uma máscara, mais do que uma verdadeira encarnação.

E essa mesma ingrata surpresa que experimentamos lendo um livro ilustrado, ao ver representado pelo ilustrador o desenho, de um modo realmente distinto daquele que imagináramos algum personagem ou alguma cena, deve experimentar sem dúvidas um autor dramático ao ver o seu drama representado por atores no teatro. Por mais que o ator se esforce para penetrar nas intenções do escritor, dificilmente conseguirá ver como este viu, sentir o personagem como o autor sentiu, encená-lo como o autor quis.

Se fosse possível tornar realidade o milagre que indiquei acima, quer dizer, se pudéssemos ver, lendo um romance, saltarem vivos do livro diante de nós os personagens, e os víssemos não mais como nós os havíamos imaginado, mas como os representou o ilus- 
trador no desenho que nos deu a ingrata surpresa, nós certamente sofreríamos como um abuso, como um pesadelo no sono, nos rebelaríamos, gritaríamos:

“Não! Assim, não! Assim, não!".

Bem, quantas vezes um pobre autor dramático, assistindo aos ensaios de uma de suas obras, não grita do mesmo modo: "Não! Assim, não!", retorcendo-se como se torturado pelo despeito, pela raiva, pela dor de não ver a tradução responder na realidade material, que deve ser necessariamente outra, à concepção e àquela execução ideal que são suas, inteiramente suas?

Mas então, pelas queixas do autor, sofre, por sua vez, o ator, o ator que vê e sente diferentemente e considera, de sua parte, como um abuso, um pesadelo, a vontade e a visão do autor. Porque o ator, se não quer (nem pode querê-lo) que as palavras escritas no drama lhe escapem pela boca como se fosse um alto-falante ou um fonógrafo, precisa voltar a conceber o personagem, concebê-lo por conta própria; precisa que a imagem já expressa volte a se realizar nele e tenda a se tornar o movimento que a efetua e a torna real no palco. Também para ele, enfim, a execução precisa saltar viva da concepção, e apenas pelos méritos dela, isto é, por movimentos promovidos pela própria imagem, viva e ativa, não somente dentro dele, mas convertida, nele e com ele, em alma e corpo.

Pois bem, embora não nasça espontaneamente no ator, mas seja suscitada em seu espírito pela expressão do poeta, essa imagem pode ser a mesma? Pode não se alterar, não se modificar, de um espírito para outro?

Já não será mais a mesma. Será talvez uma imagem aproximativa, mais ou menos semelhante, mas a mesma, não. Um dado personagem no palco dirá as mesmas palavras do drama escrito, mas nunca serão aquelas do poeta, porque o ator recriou em si, e é sua a expressão, embora não sejam suas as palavras; é sua a voz, é seu o corpo, é seu o gesto.

É precisamente o mesmo caso do tradutor.

Ilustradores, atores e tradutores se encontram, de fato, se olharmos bem, na mesma condição diante da avaliação estética. 
Mesmo sem levar em conta a última consequência da ilustração com a máquina fotográfica - em que a identidade entre ilustrador e ator é precisa, uma vez que a ilustração é feita aqui justamente por atores retratados pela máquina fotográfica no ato de interpretar com as atitudes, com a mímica, os personagens e as ações descritas e narradas pelo contador de histórias ou pelos romancistas -, consideramos o ilustrador artista, não o fotógrafo, o ator e o tradutor.

Todos estes três têm diante de si uma obra de arte já expressa, isto é, já concebida e executada por outros, que o primeiro deve traduzir noutra arte; o segundo, numa ação material; o terceiro, numa outra língua.

Como são possíveis essas traduções?

Observa corretamente Benedetto Croce na sua Estética, que não é possível reduzir aquilo que já teve sua forma estética a uma outra forma, também estética, e que, portanto, toda tradução diminui ou danifica: a expressão permanece sempre uma, aquela do original, sendo a outra mais ou menos eficiente, ou seja, não propriamente expressão; que não é possível, em suma, uma reprodução da mesma expressão original, mas, no máximo, a produção de uma expressão semelhante, mais ou menos próxima a ela.

Isso que diz Croce para as verdadeiras traduções, isto é, para quem traduz de uma língua para outra, é verdade também - como já vimos -para o ilustrador e para o ator: a diminuição e o dano também são verdadeiros em todos os três casos.

Como e por que o ilustrador corrompe e diminui a imagem do poeta, demonstrei-o no início: ele a reproduz numa arte mais limitada, dá a ela a expressão precisa, os contornos materiais, visíveis do desenho, fixa, traduz a imagem em nossas vistas, em detrimento da harmonia objetivamente espiritual dela.

E o ator?

Pois então. A realidade material, cotidiana da vida, limita as coisas, os homens e suas ações, os contraria, os deforma. Na realidade, as ações que ressaltam uma característica se destacam em contingências sem valor, de detalhes comuns. Mil obstáculos imprevistos, improvisados, desviam as ações, deturpam característi- 
cas; pequenas, vulgares misérias com frequência as diminuem. A arte liberta as coisas, os homens e as suas ações dessas contingências sem valor, desses detalhes comuns, desses vulgares obstáculos ou dessas pequenas misérias; num certo sentido, os abstrai; isto é, rejeita, sem pestanejar, tudo aquilo que contraria a concepção do artista e se atrela a tudo que, de acordo com tal concepção, lhe dá mais força e mais riqueza. Cria, assim, uma obra que não é, como a natureza, sem ordem (ao menos aparente) e plena de contradições, mas quase um pequeno mundo em que todos os elementos se unem e cooperam mutuamente. Nesse sentido, o artista, de fato, idealiza. Não que ele represente tipos ou pinte ideias; ele simplifica e concentra. A ideia que ele tem de seus personagens, o sentimento que emana deles, evocam as imagens expressivas, agrupam-nas e as combinam. Os detalhes inúteis desaparecem, tudo aquilo que é imposto pela lógica viva do personagem é reunido, concentrado na unidade de um ser menos real e, no entanto, mais verdadeiro.

Mas então, o que faz o ator? Faz exatamente o oposto do que fez o poeta. Ou seja, torna o personagem criado pelo poeta mais real, porém, menos verdadeiro, isto é, tira dele aquela verdade ideal, superior, quanto mais lhe dá daquela realidade material, comum; e o faz menos verdadeiro também porque o traduz na materialidade fictícia e convencional do palco. O ator, em suma, dá uma consistência artificial, num ambiente falso, ilusório, a pessoas e ações que já tiveram uma expressão de vida superior às contingências materiais e que vivem já na idealidade essencial e característica da poesia, isto é, numa realidade superior.

O mesmo acontece nas traduções (especificamente das poesias) de uma língua para outra. Recordemos o que dizia Dante no Convívio: "Que cada um saiba que, mesmo por vínculo harmônico das Musas, nada pode de uma língua em outra transmutar, sem quebrar toda sua doçura e harmonia".

É como transplantar uma árvore formada a outro solo, florescida sob outro clima, numa terra que não é mais a sua: sob o novo clima, perderá seu verde e suas flores; pelo verde, pelas folhas, entendamos as palavras nativas, e pelas flores, essas graças parti- 
culares da língua, sua harmonia essencial, inimitável. As palavras de uma língua têm para o povo que a fala um valor que vai além do significado, por assim dizer, material delas, e que é dado por várias coisas que escapam à uma análise mais fina, pois verdadeiramente são, como a alma, impalpáveis: toda língua inspira um sentimento particular de si, e até a forma gráfica das palavras tem valor. Se traduzimos a palavra alemã liebe com a italiana amore traduzimos o conceito da palavra, mais nada: e o som? Aquele som particular, com aquele eco tal que ele suscita sobre no espírito e sobre o qual talvez o poeta, naquele dado ponto, se referia? E a graça que deriva da colocação da colocação especial das palavras, dos construtos, das relações próprias de um dado idioma? Teremos, assim, transplantada a árvore, mas obrigando-a a se vestir com outras folhas, a florescer de outras flores; folhas e flores que brilharão e sussurrarão de outra forma, porque movidas por outra aura ideal: e a árvore, no melhor dos casos, não será mais a mesma: no pior, quanto mais nos esforçamos em fazê-la reter aquele vigor primeiro, mais miserável e apagada se mostrará.

No recente volume Pensieri e discorsi, Giovanni Pascoli fala da arte e dos modos da tradução ${ }^{2}$, especificamente dos autores clássicos antigos, e diz: “'O que é traduzir?’, assim questionava pouco tempo atrás o mais genial dos filólogos alemães, e respondia: ' $\mathrm{O}$ de fora deve se tornar novo; o de dentro, permanecer como está. Para ser mais preciso, permanece a alma, muda o corpo. A verdadeira tradução é metempsicose". Não poderia dizer melhor. Mas a contundente definição não elimina as minhas ou nossas dúvidas. Mudar de roupa (Travestie), em italiano, pode ser "travestismo", mas "travestir" em italiano soa mal. Portanto, entendamo-nos: devemos dar ao escritor antigo uma roupagem nova, mas não devemos travesti-lo. No passado, travestimos demais, conscientes ou não disso. Talvez seja causa disso os especiais destinos da língua e da literatura. O fato é que, para nós, o problema de traduzir não é tão simples. Nós não temos sempre ou não temos com frequência

${ }^{2}$ Pensieri e discorsi (Zanichelli, Bolonha, 1907). Ver La mia scuola di grammatica.

Cad. Trad., Florianópolis, v. 40, nº 2, p. 465-485, mai-ago, 2020. 
uma roupagem para oferecer ao escritor antigo de prosa ou poesia: ao menos não a temos ali, pronta; ou ao menos não sabemos que ela está ali, para ser escolhida. Além disso, na metempsicose, é correta (pelo menos no que diz respeito ao traduzir) a distinção entre corpo e alma? Não é correta. Mudando o corpo, muda-se também a alma. Trata-se, pois, não de conservar a alma do antigo num corpo novo, mas de deformá-la o menos possível; trata-se de escolher para o antigo a roupagem nova, aquela que menos o faça parecer diferente, ridículo e deselegante. Em resumo, devemos observar, ao traduzir, a mesma proporção que há no texto entre pensamento e forma, entre alma e corpo, entre o de dentro e o de fora".

Pascoli observa agudamente que não é correta a distinção entre corpo e alma: mudando de corpo, muda-se também a alma. Mas o que ele entende por corpo e alma? Por corpo entende a forma, por alma, o pensamento; e recai, ai, meu Deus!, como se De Sanctis e tantos outros homens inteligentes que, depois dele, discutiram sobre crítica clássica estética, tivessem pregado no deserto, no velho erro da crítica clássica e romântica de considerar a forma como $o$ de fora. Mas se realmente pudesse se separar o conteúdo artístico de sua forma, o corpo seria o pensamento, a alma, a forma. $\mathrm{O}$ pensamento de um escritor, antigo ou recente, o que ele quis dizer, o conceito da coisa, enfim, nós podemos apresentá-lo bem, traduzi-lo noutra língua, torná-lo compreensível de alguma maneira: mas a alma não podemos apresentá-la, a forma, que na arte é tudo. Mudando o corpo, isto é, o pensamento, muda-se também a alma, isto é, a forma. Isso é óbvio. Mas, conservando o corpo, o pensamento, pode-se lhe atribuir uma alma, uma expressão distinta? É isso o que tenta a tradução. E tenta o impossível: como reviver um cadáver introduzindo nele uma outra alma? O que Pascoli chama de $o$ de fora é justamente a expressão: mas a expressão é justamente a alma; é ele mesmo que o diz pouco depois, sem nem perceber, e de fato segue insistindo no erro em pensamento e intenção. "Há tradução e há interpretação: a obra daqueles que querem trazer o pensamento e a intenção do escritor, e a obra daqueles que buscam apenas expressar seus pontos de vista; a daque- 
les que querem que as pessoas o desfrutem e a daqueles que apenas querem que ele seja entendido. Para este último, o fidus interpres, não importa entregar verbum verbo; que se adote quantas palavras se queira, uma por várias, e várias por uma; basta compreender o que o estrangeiro diz". Não como ele o diz: portanto, o corpo, não a alma: o pensamento, não a forma. "E assim está bem”, continua Pascoli, "e esta é arte útil, necessária para quem não conhece a língua que o estrangeiro fala e o intérprete sabe". E é bom que se façam essas interpretações por escrito e em voz alta (Pascoli fala para escolares), especialmente em voz alta; e que se use a língua mais inteligível que se consiga, no quarto de hora ou de século, como muito, e seja esta o que ela queira ser, desleixada ou impulsiva. Mas a interpretação, na escola, deve ter a tradução por trás: ou seja, o escritor morto, cujos compatriotas e língua morreram, deve vir diante de nós e nos falar em nossa nova língua, ou seja, não eu ou vocês, mas o seu pensamento, que já está expresso em sua língua antiga (o grifo é meu). Dizer isso à sua maneira, tão bem ou não tão bem como já estava dito: de modo simples, se era simples, pomposo, se era pomposo; e, se amava as palavras antigas, que se busquem agora as palavras antigas em nossa língua, e se preferia as frases poéticas, que não se rebusquem as falas do povo ${ }^{3}$.

${ }^{3}$ Pascoli repete mais ou menos aqui uma observação de Leopardi (Pensieri di varia filosofia e di bella lett., vol. I, p. 89-90): “Uma observação importantíssima em torno às traduções, e que não sei se outros a fizeram e da qual não sei se alguém se aproveitou, é a seguinte. Muitas vezes encontramos no autor que traduzimos, por exemplo, grego, uma composição, uma palavra que nos parece audaciosa, e ao traduzi-la tentamos encontrar uma que a equivalha, e com isso nos contentamos. Mas muito frequentemente essa composição ou essa palavra, ainda que o seja, não é apenas audaciosa, senão que o autor a formou propositalmente, e nos leitores gregos dava justamente essa impressão e ressaltava no escrito como fazem as palavras novas, e como em nós, italianos, fazem aquelas muitas palavras de Alfieri, por exemplo, spiemontizzare, etc. Se na sua tradução você encontrou uma palavra muito correspondente, adequada, equivalente, mesmo assim você não terá feito nada se essa palavra não for nova e não provocar em nós a mesma impressão que causava nos gregos". É curioso notar, no entanto, que Pascoli torna difícil para nós o exercício de traduzir, e diz: "Para isso é necessário estudar e se dedicar: rejuvenescer, com frequência, aquilo que na nossa língua parecia 
Estarão estes muito mais nas nossas do que nas suas páginas: oh, sim!, mortos às vezes ou sempre, ao invés de vivos; sombras e não corpos; mas as sombras se assemelham perfeitamente aos corpos; as sombras, como as dos heróis, conservam nos Elíseos dos poetas os mesmos gostos que tinham na terra. Se quisermos evocá-los na nossa língua, esses, quando obedeçam, querem ser e parecer o que foram; e nós não somente não devemos mutilá-los e enfeá-los, mas tampouco (algo que com frequência pensamos fazer) corrigi-los e embelezá-los; seria como tirar de Homero os acréscimos ociosos de cantor herdeiro de cantores ${ }^{4}$, e de Heródoto sua lentidão de narrador claro, e de Cícero suas redundâncias de narrador harmonioso, e de Tácito suas cores poéticas de escritor esquivo para o povo. Cada um deve deixar adivinhar, se não sentir, as predileções que tinha quando vivo, no que se refere à língua e à rima e ao número e ao ritmo.

Mais alma que isso! Se bem que, na verdade, Pascoli, entre os pequenos indícios de sua preciosíssima prosa, nunca consegue enxergar bem a questão. E isso se argumenta facilmente inclusive através daquilo que diz acerca do número e do ritmo. Pergunta: "Por exemplo, o verso livre de Caro e de Monti é demasiadamente livre; quer dizer, mesmo sem conseguir com cada hendecassílabo compreender um hexâmetro, não se preocupa em compreender

morto; encontrar, não raramente, algo que ainda não há em nossa literatura. Digo e repito, na nossa: talvez os outros povos não necessitem de tanto esforço. E, sim: às vezes para nós falta aquilo que em outros transborda". Exatamente o contrário nos diz Leopardi (Pens. ecc., vol. II, p. 302): “... na italiana é talvez maior que em qualquer outra a faculdade de se adaptar às formas estrangeiras”. Demonstra o porquê, e ainda acrescenta: "Estas considerações a respeito dessa faculdade de nossa língua, aumentam quando se trata da língua latina ou grega". E diz as razões desse fato. Agudíssimo, como de costume, se revela Leopardi ao falar das traduções em vários pontos da tradução do Zibaldone. Citarei, por exemplo, aquilo que diz no vol. I (p. 388-9), depois de ter tratado da inevitável afetação de cada tradutor: "A tradução não é tradução, mas uma imitação sofista, uma compilação, uma cabeça morta, ou então uma nova obra”.

${ }^{4}$ Alude evidentemente às justas críticas feitas por Zanella na tradução da Odisseia de Pindemonte. 
dois com três, sempre, metódica e monotonamente, como eu acho que deveria ser? Bem, nós provaremos; faremos nós os tercetos, com rima consoante, assoante ou livres. Ou provaremos traduzir com o hexâmetro itálico. Mas será que o hexâmetro de Carducci vai nos parecer muito livre de sotaque? Nós nos esforçaremos para fazê-lo tão regular, tão sonoro, quanto o são pelo menos aqueles de Voss e de Geibel".

Como se por opção se pudesse traduzir um poeta antigo ou estrangeiro, que compõe em hexâmetros, em versos livres, em tercetos consoantes, assoantes ou livres, ou no seu metro original! Recordo-me do que dizia Goethe a respeito de suas Elegias romanas: "Traduzidas no ritmo do Don Giovanni de Byron (isto é, em oitavas), as minhas Elegias romanas seriam uma obra totalmente sem sentido (ganz verrückt)". É verdade que Maffei as traduziu em verso livre, deixando inclusive os versos pela metade nalgumas elegias; e Domenico Gnoli, que ainda não era o Giulio Orsini dos versos livres, traduziu-as em tercetos consoantes, quer dizer, no metro clássico e tradicional da elegia na literatura italiana. Pascoli, na verdade, ofereceu ensaios muito admirados de tradução de Homero em hexâmetros, não em tercetos ou verso livre; mas também é verdade, ao menos no meu ponto de vista, que aqueles ensaios não estão totalmente isentos daquela afetação que, para Leopardi, era indiscutível em cada tradutor.

O conde de Caylus queria que o maior ou menor valor de uma poesia fosse julgada segundo a possibilidade de ela ser ou não traduzida em quadros por um pintor. Da mesma maneira, o maior ou menor valor de um drama se julgaria pela prova da representação; aliás, diz-se que não é possível dar um juízo sobre um drama escrito, quer dizer, já expresso pelo poeta. Já demonstramos que a do teatro não é a representação verdadeira da expressão genuína, original, mas uma tradução, isto é, uma expressão similar, mais ou menos próxima à original; nunca a mesma; e demos as razões pelas quais é também mais ou menos falha e reduzida.

Embora em medida muito menor, pode-se dizer o mesmo daquela tradução que cada um faz da obra de outro, se não no próprio 
ato de lê-la, durante o qual o espírito está disposto a acolher e refletir em si ou as ideias que o escritor expõe, ou as expressões que a obra quer despertar, pelo menos quando nos referimos a outros ou também a nós mesmos aquelas ideias e impressões recebidas da leitura, isto é, quando nós repensamos a obra lida. Feita a passagem de um espírito a outro, as mudanças são inevitáveis. Quantos escritores não ficam dolorosamente maravilhados ao ver o que sua própria obra se tornou através do espírito deste ou daquele leitor, que talvez o felicitem por certos efeitos dos quais ele nem sequer sonhou em produzir! "Como você me fez rir!" - e o escritor não tinha a menor intenção de provocar o menor riso! E como é raro ocorrer que os escritores se deleitem ao ver que suas próprias obras são, para um crítico ou um leitor, o mesmo ou mais ou menos o mesmo que eles expressaram, e não outra mal repensada e arbitrariamente reproduzida.

Consiste justamente nisso a suma dificuldade da crítica. É preciso antes de tudo não presumir que os outros, fora de nosso eu, sejam apenas como nós os vemos. Se presumirmos dessa forma, quer dizer que temos uma consciência unilateral; que não temos consciência dos outros; que não realizamos os outros em nós, para usar uma expressão de Iosiah Royce, com uma representação viva, para os outros e para nós. $\mathrm{O}$ mundo não se limita à ideia que dele podemos fazer: fora de nós, o mundo existe por si e conosco; e em nossa representação, portanto, podemos nos propor de realizá-lo o máximo possível, fazendo dele uma consciência em que ele viva, em nós e em si mesmo; vendo-o como ele se vê, sentindo-o como ele se sente.

Ora, essa obra de realização é extremamente difícil! Pode ocorrer, e ocorre não raramente, que nós, à medida que lemos, repensemos melhor aquilo que o escritor pensou, expressemos melhor em nós aquilo que o autor expressou mal ou não expressou de fato, que nós encontremos num livro aquilo que no fundo não há: que realizemos nós, em suma, aquilo que o autor não conseguiu realizar.

É o mesmo caso do comediante que, na representação teatral, melhora e não estraga, acresce e não diminui o drama que lhe foi confiado. Mas, neste caso (que não verdade não é pouco frequente), 
o mérito é do ator; e o drama é ruim. Assim, mesmo uma tradução pode ser melhor que o original; mas então é a tradução que se torna o original, pois o tradutor tomou como matéria bruta o original e o recriou com a sua fantasia: tal como o ator tomou o drama como um papel qualquer e lhe deu vida no palco. O mesmo caso também pode se repetir para aqueles ilustradores que tomam como matéria não convenientemente expressa as obras daqueles escritores secundários, descritivos ou decorativos, que têm uma imaginação pictórica e não conseguem naturalmente mostrar, com o incoerente meio comunicativo da palavra, os seus quadros.

Recentemente, um jornal de Roma convocou um referendo entre nossos escritores de teatro para saber se os atores tinham ou não o direito de julgar os dramas e as comédias que lhes propunham representar; ou, noutros termos, se os atores deviam ou não ser considerados como instrumentos mais ou menos competentes de comunicação entre o escritor e o público, único juiz legítimo.

Nenhum entre todos os que responderam às perguntas do referendo soube ir além, a uma questão mais alta, algo que um espírito mais agudo e compreensivo poderia pairar sobre aquelas perguntas. Diz-se comumente que o autor nunca é um bom juiz da própria obra e que o ator não sabe reconhecer as qualidades artísticas do drama, pois busca neste apenas a parte boa, e se a encontra, o drama é bom, e se não a encontra, é ruim.

É fato que a reflexão, para o escritor, é quase uma forma de sentimento: à medida que a obra é feita, ele a critica, não friamente, como faria um juiz desapaixonado, analisando-a, mas de repente, a partir da impressão que dela recebe. A obra, enfim, é no escritor um sentimento análogo àquele que ela desperta no espectador: ela é vivenciada, mais do que julgada.

O mesmo acontece com o ator, que não pode ser de fato considerado como um instrumento mecânico ou passivo de comunicação. Se ele examinasse friamente a obra que deve representar, como o faria um juiz desapaixonado, analisando-a, e desse exame frio, dessa análise desapaixonada quisesse alçar à interpretação de sua parte, nunca conseguiria dar vida a um personagem no palco. 
Justamente como nunca conseguiria fazer uma obra viva um escritor que não sentisse primeiro o sentimento inspirador, a visão do todo, e compusesse pedacinho por pedacinho os vários elementos até reuni-los com um trabalho de composição reflexiva, como uma conclusão construída com base num raciocínio. O ator, em suma, experimenta, não julga. Tal como o escritor sente de improviso, através de uma emoção, de uma simpatia repentina, de um acaso da vida, comum e inexpressivo para os outros, ou de uma narrativa da história, o sujeito que lhe convém; da mesma forma o ator precisa sentir através de uma emoção, de uma simpatia repentina a parte que lhe convém, experimentar em si mesmo o personagem a que deve dar vida no palco.

Porém, naturalmente o ator, vivendo no teatro - isto é, entre aquilo que há de falso e convencional num palco -, é geralmente induzido a ver na obra de arte sobretudo aquilo que ela tem de teatral (tal como o desenhista que, num livro que lhe seja dado a ilustrar, não vê se não aquilo que mais se preste à ilustração). Em síntese, o ator, mais que as razões ideais da arte, vê naqueles materiais do palco, mais que a verdade superior da expressão artística, a realidade fictícia de sua ação cênica.

Ora, não renunciam talvez, por causa dessa realidade fictícia e falsa do palco, àquela verdade superior, essencial e característica da arte, os escritores de teatro que compõem dramas para este ou aquele ator? Não estão eles, num certo sentido, diante de uma estimativa estética, na mesma linha daqueles poetas que se prestam a fazer o poeminha sob os desenhos de certas revistas ilustradas? Uns e outros à sua maneira demonstram não entender o grau de idealismo e a dignidade de sua arte. Mas são sempre sem dúvidas mais dignos de perdão os escritores de teatro, porque, no fundo, assim procedendo, obedecem a uma triste necessidade de sua arte. Preocupando-se, no entanto, não com as criaturas de sua fantasia, mas com este ator ou aquela atriz da cena em prosa, e deixando-se infelizmente inspirar ou sugerir pelo virtuosismo destes; partindo de uma tal consideração mais ou menos prática e deduzindo da própria obra, mediante o frio raciocínio, as imagens já fixadas an- 
teriormente, encarnadas neste ou naquele ator, que obras podem surgir? Obras escravas, antes de tudo, desses mesmos atores, de seus recursos e suas atitudes; escravas, e não da arte; porque a arte tem uma necessidade imprescindível de sua liberdade.

Não é o drama que faz as pessoas, mas as pessoas o drama; antes de qualquer coisa é preciso ter as pessoas, mas livres. Com elas e nelas nascerá o drama. Cada ideia, cada ação, para que apareçam em ato, vivas diante de nossos olhos, necessitam da livre individualidade humana, em que se mostrem como movente afetivo: precisam, portanto, de personagens. O personagem será tão ou mais determinado e superior quanto menos seja ou se mostre submisso à intenção ou aos modos do autor, à necessidade de desenvolvimento do fato imaginado; quanto menos se mostre instrumento passivo de uma dada ação, e, por outro lado, quanto mais mostre em cada ato seu um caráter próprio e, ao mesmo tempo, uma especificidade concreta.

São assim os personagens de Shakespeare. E, aqui, os ilustradores de teatro não podem triunfar facilmente. Por que, de fato, são tão poucos os dignos intérpretes de Shakespeare? Ora, porque suas figuras trágicas são tão grandiosas e têm tão fortemente marcados os seus traços característicos, que apenas alguns poucos conseguem enchê-las de si, e quem delas quiser traçá-la a seu modo, no desenho da cena, subitamente mostra sua pequenez, sua ridícula mesquinharia.

Uma coisa é o drama, obra de arte já expressa e viva no seu idealismo essencial e característico; outra é a representação cênica, tradução e interpretação daquela obra, cópia mais ou menos semelhante que vive numa realidade material, e, contudo, fictícia e ilusória. Se quisermos extrair as últimas consequências dessa investigação estética, se não quisermos uma tradução mais ou menos fiel, mas o original verdadeiramente no teatro, eis a comédia da arte: um esquema embrionário, e a livre criação do ator. Seria sempre trivial, porque obra de improvisação, na qual não pode ocorrer o desperdício de detalhes óbvios, comuns, aquela simplificação e concentração ideal, característica de toda obra de arte superior. 


\section{Referências}

Pirandello, Luigi. "Illustratori, attori e traduttori". In: Pirandello, Luigi. Arte e scienza. Roma: W.Modes Libraio-Editore, 1908.

Recebido em: 20/01/2020

Aceito em: 07/04/2020

Publicado em maio de 2020

Diego Silveira Coelho Ferreira. E-mail: diegosilveiracf@gmail.com ORCID: https://orcid.org/0000-0002-8629-4921.

Andréia Guerini. E-mail: andreia.guerini@gmail.com ORCID: https://orcid. org/0000-0002-3187-6246 